\title{
Copyright Research in the Digital Age: Moving from Piracy to the Supply of New Products \\ By JOEL WALDFOGEL*
}

*Waldfogel: Carlson School of Management, University of Minnesota, $32119^{\text {th }}$ Ave. S., Minneapolis, MN 55455 and NBER, 1050 Massachusetts Ave., Cambridge, MA 02138 (e-mail: jwaldfogel@umn.edu).

In the dozen years since the widespread adoption of the Internet, firms selling digitizable content - text, music, and video have experienced serious threats to their traditional revenue sources. The recorded music industry was the first to face the threat; after seeing its revenues rise for decades prior to 1999 , revenues have fallen steadily since, both in the US and internationally. Music is not the only sector that has seen its fortunes decline. The US newspaper industry has also experienced a substantial reduction in revenue that most observers attribute to the arrival of the Internet. ${ }^{1}$

These events have spawned a substantial volume of research, most of which has been focused on the impacts of technological change on appropriable revenue. A large and still-growing literature explores whether consumers' ability to obtain recorded music

\footnotetext{
1 The Newspaper Association of American reports that US newspaper ad revenue, including digital, halved between 2004 and 2010. See http://www.naa.org/Trends-and-Numbers/AdvertisingExpenditures/Annual-All-Categories.aspx).
}

without paying reduces sellers' ability to generate revenue from selling recorded music. $^{2}$ Most studies find depressing effects of unpaid consumption on paid consumption.

While the sales displacement question is of understandable importance to both researchers and, especially, to the affected industries, a decade into this research endeavor, it may be time to devote more attention to other aspects of the technological revolution we are now experiencing.

Below I advance this argument, in the following sections. First, I offer a brief recent history of travel agents, as a point of comparison with the digital content industries. Second, I present a simple economic framework for organizing our thinking about the effects of technological change on content industries, including effects on demand, marginal costs, and on fixed costs. Third, I discuss how digitization may affect the level of copyright protection needed to assure a steady flow of new creative work. I then turn to the set of research questions implied by

\footnotetext{
2 See, for example, Oberholzer-Gee and Strumpf (2007), Liebowitz (2006), Zentner (2006), or Rob and Waldfogel (2006).
} 
these technological developments, including the focus of most existing work (measurement of sales displacement caused by unpaid consumption), along with other questions that may warrant more attention: i) new pricing and distribution models possible with zero marginal costs, ii) effects on the development of new products given that costs have declined, and iii) effects on consumer discovery of new products, given the possible proliferation of new products.

\section{The Parable of the Travel Agents}

In 1975 the main way to arrange air travel was to dial a telephone to speak with an agent with access to a computer terminal connected to a registration system. A typical call lasted perhaps 15 minutes as the agent reviewed the available flights and fares. The fruits of travel agents' work were evident in the stunning growth of air travel following the airline deregulation of the late 1970s: Between 1975 and 2000, the volume of US air travel tripled (from 200 million to 640 million revenue passengers per year), and the number of travel agents grew apace, from 45,000 to $124,000 .^{3}$ Travel agents were performing a

\footnotetext{
3 See air carrier departure data provided by the Bureau of Transportation Statistics, www.bts.gov/publications/national_transportation_statistics/html/tabl e_01_37.html.
}

useful function in the economy, acting as intermediaries between consumers and air carriers, helping consumers to choose among a complicated and even bewildering array of options.

Around the year 2000 something unusual happened. Travel agents - at least in their capacity as travel agents - began to disappear. Ten percent disappeared in 2001; another 6 percent disappeared in 2002. By 2010, 43 percent of the travel agents working in 2000 had disappeared from the employment rolls.

In the late 1990s, not long after the initial spread of the Internet to businesses and households, a number of Internet travel sites including Travelocity, Expedia, Priceline, and Orbitz - appeared on the scene. ${ }^{4}$ Individual airlines also launched sites selling their own tickets. Consumers shifted to these sites rapidly. By 2010, roughly a third of travel was being booked using web retailers rather than interaction with human agents. ${ }^{5}$ A large share was booked using the airlines' own online sites. ${ }^{6}$

\footnotetext{
4

Travelocity and Expedia appeared in 1996 (en.wikipedia.org/wiki/Travelocity; en.wikipedia.org/wiki/Expedia,_Inc. ); Orbitz began in 2001 (en.wikipedia.org/wiki/Orbitz). ${ }^{5}$ See clients.ibisworld.com/industryus/Majorcompanies.aspx?indid=1481 .

6 Figures on travel agent employment are drawn from various issues of the Bureau of Labor Statistics Occupational Employment Statistics, available at www.bls.gov/oes/.
} 
Given their indispensible role in helping travelers navigate the market prior to 2000, one might have expected their disappearance to create some turbulence in the market for airplane tickets. But no such disruption occurred. Despite a dip in travel following 9/11, air travel continued its upward trend, reaching 740 million revenue passengers in 2007.

Travel agents did not go down without some fight. Protesting the Internet's inroads, they enjoined Congress in 2000 to establish a "National Commission to Ensure Consumer Information and Choice in the Airline Industry" and charged it to "undertake a study of... whether the financial condition of travel agents is declining..." The Commission was instructed to "pay special attention to the condition of travel agencies with $\$ 1,000,000$ or less in annual revenues.” Finally, the Commission was chartered to "make such recommendations as it considers necessary to improve the condition of travel agents."7

It is understandable that the travel agents would face economic distress in the face of the threat from the Internet. But the question of whether government should have granted them economic relief was answered negatively by the fact that online sites reduced costs and

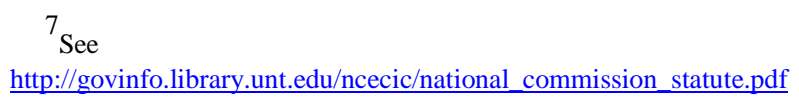

promoted convenience. As Robert Atkinson put it in Progressive Policy Institute testimony, "Airlines should be allowed to provide their lowest fares to sites like Orbitz because dealing with them does not cost the airlines as much money as dealing with a travel agent. The whole point of web fares is to encourage consumers to use the Internet to book tickets because this is the low cost channel."8

The analogy between travel agents and, say, the recorded music industry is, of course, imperfect. Music industry revenue is declining because consumers are "sharing" music rather than paying for it, whereas travel agent employment fell because consumers turned from one legal source of travel intermediation to another. But the analogy does point us to a crucial question. We ultimately did not care about the decline of travel agent employment because travel continued to rise even as travel agents disappeared. What is analogue of air travel in the recorded music industry example? And has it declined along with recorded music revenue?

\section{Keeping Track of Digitization}

Prior to the Internet and related technological developments, music, text, and

\footnotetext{
${ }^{8}$ See

http://govinfo.library.unt.edu/ncecic/other_testimony/progressive_pol icy_institute.pdf.
} 
video products had high fixed costs and low (but not zero) marginal costs. These products

- books, newspapers, music recordings, and movies - are differentiated within category and therefore also faced downward sloping demand curves. Digitization has had impacts on all three elements: demand, marginal costs, and fixed costs.

First, as is well known, digitization has affected demand. In particular, digitization has facilitated unpaid consumption which has, in effect, reduced appropriable revenue. There is, as mentioned above, some debate about the size of this effect, but a reduction in appropriability makes it more difficult to generate revenue for any given product.

The welfare analysis of weakened appropriability is somewhat nuanced. For products that already exist, a weakened ability to charge consumers for us promotes transfers from producers to consumers. This transfer is, of course, bad news for producers and, in the short run, good news for consumers. Moreover, it promotes the transformation of deadweight loss into consumer surplus. This second piece is good news for consumers without offsetting bad news for sellers.

Of course, because weakened appropriability reduces revenue, it can also undermine the creation of new products in the future. This is potentially bad for both producers and consumers.

Second, digitization has reduced the marginal cost of digital products to essentially zero. Books, music, and movies can now be reproduced and distributed with negligible cost. This, by itself, is good news for all parties. With lower marginal costs, some combination of producer and consumer surplus can increase. If prices fall, as one might expect, then deadweight loss can fall as well.

Finally, digitization can reduce the costs of bringing new products to market. That is, digitization can reduce fixed, or sunk, costs. By itself, this would increase the number of products coming to market. And, alone, it would tend to help consumers. Whether it helps producers is unclear. Existing producers would face more competition. New entrants would have a previously unavailable opportunity to reach consumers.

While digitization has affected these three distinct elements (demand, MC, and FC), with varying theoretical impacts on producers and consumers, research to date has focused primarily on one possible channel - the negative impact of reduced effective demand on revenue. This is, of course, important. But the other channels all deserve attention. 


\section{Digitization and Copyright}

Copyright law allows creators monopolies over the sale of their creative works. These legal grants of monopoly embody all of the usual bad features of monopoly: they ensure that works will be more expensive than they otherwise might be. (In a zero marginal cost world without perfect price discrimination, these monopolies tend to guarantee that there will be some deadweight loss associated with situations with positive prices).

But this negative feature is supposed to be offset by the monopolies' incentive effects on creation. That is, the prospect of monopoly profits is supposed to provide incentives for bringing new works to market. This is, of course, good for both producers, who get profits and for consumers, who get new products they value above the prices they pay.

The costs of creating books, movies, and recorded music are largely (now almost exclusively) fixed; and these fixed costs have traditionally been large. Hence it is perhaps understandable that creators needed substantial copyright protection to give them some assurance that they could finance their investments. But as argued above, if costs of creation have declined, holding other things constant, it would be possible for effective copyright protection to recently have grown stronger. Of course, all things are not constant. Piracy weakened effective copyright protection. But together, reduced costs of bringing new works to market along with weakened appropriability have an ambiguous impact on the level of copyright protection needed to maintain any particular flow of new works.

We can see this in a simple model of optimal copyright. Suppose a rights holder faces a linear downward-sloping inverse demand curve $p=a-b q$ and that costs include a one-time sunk component $(k)$ plus a fixed marginal component $c$. Then a rights holder generates annual variable profits of ( $a-$ $c)^{2} / 4 b$. If there is no discounting, then define the optimal copyright term as the number of years $\mathrm{t}$ such that period profits cover development costs: $t^{*}=4 k b /(a-c)^{2}$. The comparative statics are straightforward: lower development costs reduce optimal term, while weaker demand (higher $b$ ) raises the optimal term.

A simple shorthand for the digital era is that $k$ has fallen while $b$ has risen, so we don't know whether copyright protection would need to be strengthened or weakened to preserve creative incentives existing a few decades ago.

\section{A Research Agenda}


We are fortunate to be living in interesting times, that is, through some substantial technological changes. But what are the important research questions? Revisiting the travel agent example provides a little perspective.

One question that researchers might want to answer is whether the use of online travel sites for securing tickets reduces the demand for human travel agents. This seems like a fairly easy question, so the research community would quickly reach consensus that online travel site transactions displace transactions with human agents roughly one-for-one.

Someone would notice that even though travel agent employment was down, actual air travel had continued to rise. Because consumers have no interest in travel agents per se but are instead interested in travel, observers would conclude that the decline in travel agent employment was not a problem to be solved but instead a happy consequence of technological change.

Turning to digitization and copyright, the first question is, "what is the digitization analogue of air travel?” And has it increased? This, in turn has various parts: has creative activity continued despite the reduction in appropriability? Is the new work of high quality? Are consumers able to discover new products? How do artists support themselves if not by selling recorded music? What new business models are made possible by zero marginal cost distribution, and are these approaches benefiting consumers and producers? I discuss some emerging research opportunities in these areas below.

\section{The quality and quantity of new work}

I would argue that the analogue of air travel in this context is the service flow of new creative goods.

While digitization has weakened demand, it has also reduced both fixed and marginal costs. Theory gives no clear guidance on whether to expect the flow of products to have ebbed.

Researchers have begun to address these questions with evidence of record label entry and a growth in new titles. ${ }^{9}$ These facts are quite interesting, but they do not allow us to compare the quality of new music to its quality in earlier periods.

I have also participated in this discussion, with evidence that the quality of new recorded music products has not fallen - and may well have risen - in the decade following

\footnotetext{
9 Handke (2006, 2010) documents growth in the number of German record labels operating. Oberholzer-Gee and Stumpf (2009) document a growth in the number of new musical recordings made available annually in the years since Napster.
} 
Napster. ${ }^{10}$ In one approach I use critics' bestof lists (such as best of the decade or best of all time) to create indices of the number of high quality works originally released in each year. I statistically combine these indices to produce an overall index of music quality, and it does not decline following Napster.

In a second approach, I develop an index of music quality with usage data (sales and airplay) by time and vintage. The idea is simple. Older music sells less and is aired less on radio because consumers have less interest in older material. But after accounting for this depreciation, the vintages that are used more heavily must have higher quality. Indices derived from this approach show an increase in music quality since Napster.

\section{Product discovery in the digital world}

A second question concerns possible changed modes of new product discovery. Record labels have traditionally played major roles in production, promotion, and distribution of music. It is clear that new technologies have revolutionized production and distribution. Where an artist once needed expensive equipment and skilled labor to record music, it is now possible to do so with

\footnotetext{
10 See Waldfogel (2011a,b).
}

a modest computer and inexpensive software. And while distribution once required facilities for making physical albums along with transportation resources and relationships with retailers, artists can now make their recordings available at iTunes for an investment of roughly $\$ 10$.

The major remaining challenge is making consumers aware of one's music. Music is an experience good, and consumers must hear it in order to become interested in buying it. Radio airplay provided the traditional means for familiarizing consumers with music. The number of new works aired on radio stations was always a small share of new works created, so radio provided a natural bottleneck; and getting songs on the radio was a major component of costs for major record labels.

The growth of Internet radio - in particular sites like Pandora, Last.fm, and Spotify - has raised the possibility of promotion that circumvents the traditional radio bottleneck and its substantial costs. Yet, it is not clear whether the mere availability of a wide variety of music would lead to the consumption of a wider variety. Radio provided an editorial or “curation” function, choosing a limited set of works with which to acquaint consumers. What will play this role now? 
One possibility source of opinion-making is music critics. Music criticism was traditionally confined to print publications, but the growth of the Internet has been accompanied by a substantial growth in outlets offering music criticism. Metacritic.com is a website offering distilled numerical ratings of new music. They have operated since 2000, and they draw from over 100 sources of professional music criticism. Metacritic includes a review of at least three of its underlying sources review an album. Their reviews have increased from 222 in 2000 to 835 in 2010. Underlying sources include originally-offline magazines such as Rolling Stone, as well as newspapers. But many sources, such as Pitchfork, came into existence with, or since, the Internet. Of the reviews in Metacritic for albums released since 2000, over half are from sources founded since 1995. If these outlets can inform consumers about music, they may supplant the traditional role of radio.

\section{New Business Models}

Distribution at zero marginal cost makes possible a variety of new business models that may promote the continued financing of new musical creation. First, as some authors have usefully emphasized, recorded music stimulates interest in live performance; and live music has grown more robust over the past decade. ${ }^{11}$ Second, production at zero marginal cost makes possible marketing arrangements such as pure and mixed bundling, nonlinear pricing, and two-part tariffs that had until recently been largely topics for theoretical speculation, at least in markets for copyright-protected products.

It has now been over a decade since the Internet and related technologies began having their revolutionary effects on content industries, spawning a great deal of interesting research. As we look ahead, there are many topics meriting further study that will merit researchers' attention in the coming decade. 


\section{REFERENCES}

Connolly, Marie \& Krueger, Alan B., 2006. "Rockonomics: The Economics of Popular Music," Handbook of the Economics of Art and Culture, Elsevier.

Handke, Christian. "Plain Destruction or Creative Destruction? Copyright Erosion and the Evolution of the Record Industry." Review of Economic Research on Copyright Issues, 2006, vol 3(2): 29-51.

Handke, Christian, "Digital Copying and the Supply of Sound Recordings.” Unpublished Manuscript, 2010, available at http://www.acei2010.com/upload/acei/hand ke.pdf .

Liebowitz, Stan J. "File Sharing: Creative Destruction or Just Plain Destruction?” Journal of Law and Economics, vol. 49, no. 1, April 2006, pp. 1-28.

Oberholzer-Gee, Felix and Koleman Strumpf. "The Effect of File Sharing on Record Sales: An Empirical Analysis.” Journal of Political Economy. Volume 115, Issue 1, Page 1-42, Feb 2007.

Oberholzer-Gee, Felix and Koleman Strumpf. File-Sharing and Copyright. NBER's Innovation Policy and the Economy series, volume 10. ed. Joshua Lerner and Scott Stern. MIT Press. 2009.

Mortimer, Julie Holland, Chris Nosko, and Alan Sorensen. "Supply Responses to
Digital Distribution: Recorded Music and Live Performances.” NBER Working Paper No. 16507. October 2010.

Rob, Rafael and Joel Waldfogel. "Piracy on the High C's: Music Downloading, Sales Displacement, and Social Welfare in a Sample of College Students." Journal of Law \& Economics. Volume 49, Issue 1, Page 29-62, Apr 2006.

Waldfogel, Joel. “Bye, Bye, Miss American Pie: The Supply of New Recorded Music since Napster." NBER Working Paper 16258. 2011a.

Waldfogel, Joel. “The Quality of Recorded Music since Napster: Evidence Based on the Vintage Distribution of Sales and Airplay.” NBER Working Paper 17503, 2011b.

Zentner, Alejandro, "Measuring the Effect of File Sharing on Music Purchases.” The Journal of Law and Economics. Volume 49, Issue 1, Page 63-90, Apr 2006. 
